\title{
Social Movements in Europe, from the Past to the Present
}

\section{Célia Taborda Silva}

Associate Professor, Lusófona University of Porto

\section{Abstract}

Over time, the concept of social movement has evolved as society has changed, but has always implied collective action in the public space. The form of social contestation has changed, according to the conjuncture of each historical period. In 18th century, the transition from the Old Regime to Liberalism provoked movements considered by some authors as "primitive" or "premodern", as they were spontaneous, sporadic and depoliticized. Industrial society of the 19th century gave rise to the labor movement and trade unionism, which from then on organized the social movements. In the 20th century there were changes and innovation in the collective way of acting, there was the emergence of a series of social movements that differ from the traditional in terms of the objectives and actors involved, such as the pacifist, ecologist, feminist movements, acting on the fringes of parties and unions. The 21st century has witnessed a set of movements that begin on social networks, such as Generation Scratch, Outraged, Occupy Wall Street, Screw the Troika, and quickly outgrow local scales to become global. Through the use of a theoretical and conceptual framework derived from the theories of social movements and taking into account the current transformation of collective action that has been witnessed in the 21st century, we intend to verify if we are facing a new social phenomenon or another phase of "repertoire" change.

Keywords: social movements, past, present, evolution, repertoire

\section{Introduction}

The 21st century was born under the aegis of contestation. A number of social movements have been plaguing the world in recent times. Therefore, it is interesting to revisit the concept in order to understand its own historical evolution and what has changed over time in social movements. Tilly (1978), precisely, assumes that social movements require historical understanding and tried to understand them in the convergence between Sociology and History (1981), very much in the style of the Braudelian "longue durée", to capture permanence or change, the immobility or innovation. Seen from a historical perspective, social movements have presented themselves over time as forms of collective action in which certain actors have intervened, in a given political, socioeconomic and cultural context.

There are two theoretical currents (Gohn, 1997) for the interpretation of social movements: the European and the North American. Both have a classic and a contemporary paradigm of interpreting movements. The European one was initially based on the historical-structuralist current and later on the theory of New Social Movements. The American, until the sixties, based her interpretation on social movements in the functionalist theory about collective 
behavior and in the contemporary Theories of Resource Mobilization (TRM) and Political Process (TPP).

In Europe, the classical approach was based on Marxism, largely based on class struggle, in which social movements resulted from the conflict between dominators and the dominated. This interpretation did not justify the movements that emerged in the sixties, resulting from post-industrialization, in which the demands were no longer centered on material issues but on new ways of affirming rights and ways of life. The movements that emerged at that time were, therefore, called New Social Movements (N.S.M.), as they moved away from Marxist reductionism, with collective actions now having other motivations on the basis of which were identity and cultural issues, which allowed forging collective behavior.

The American paradigm developed around the Chicago School and classical theory said that it was sociopsychological factors that explained collective behavior. The deviation from normal and traditional relations due to the social anomie derived from industrialization was what led to collective action motivated by unconscious and irrational impulses. These positions were also revised in the 1960s in the face of the emergence of feminist, pacifist (against the Vietnam War), ethnic movements. Psychology was rejected as a way of explaining collective action and theories emerged, such as the Theory of Resource Mobilization and Theory of Political Process (MCadam, Tarrow and Tilly, 2001) that considered that the explanation for the emergence of movements was not found in irrationality or social alienation of the participants but rather in the political opportunities or threats, in the material and non-material resources available socially in a given period and in the way they were used to achieve certain ends. In fact, the defenders of these theories consider that insertion in a community leads to more action than uprooting or alienation.

These theories (European and North American), from the eighties, nineties, came to be seen as complementary and conciliatory (Cohen, 1985; Della Porta and Diani, 1999; Diani, 1992), reason why we will try to understand the Europeans movements through the use of a theoretical and conceptual framework derived from the theories and historiography of social movements and using the concept of the "repertoire" of the American sociologist Charles Tilly.

For Tilly, what happened historically in collective action was a change in the "repertoire". The author defines a "repertoire" as a "set of forms of action" (Tilly, 1978: 156) and each era has its own structures of mobilization and action, generally forged from the oldest actions (1995: 27-28). Changing political and social structures usually results in a change in the "repertoire" (Tilly, 1995, p. 35).

In this sense, given the current transformation of collective action that has been witnessing in the 21st century, will European social movements be in yet another phase of innovation / adaptation in the "repertoire" or will we be facing a new "repertoire"?

\section{1. "Pre-modern", archaic or primitive movements}

Social contestation has been a constant throughout history, generating various types of social movements depending on the period in which they occurred. The transition from the Old Regime to Liberalism provoked upheavals considered by some authors like Eric Hobsbawm or Edward Thompson to be "primitive" or "pre-modern". These protests arose from the confrontation between the capitalist system and the traditional social organization. Adaptation or inability to adapt resulted in social movements, among which banditry stands out, peasant revolutionary movements of the millenarian genre, rural secret societies 
(Hobsbawm, 1978: 11), studied by Hobsbawm in Spain and Italy, classifying the author this type of protest as "archaic" or "primitive" forms of social unrest. Within the same type of premodern revolt are also the food riots, studied by Thompson for England (1979, pp. 62-134).

These pre-modern agitations have not been the subject of much analysis, nor have they been given great importance, because they are outside the classification established for modern social movements, that is, those that have occurred since the end of the 18th century. These are protests that could best fit into the occasional phenomena that arose in the Middle Ages, but the truth is that they took place in the 19th and 20th centuries, having therefore coexisted with modern protest movements. Those involved in these primitive movements had not yet found a specific language to express their aspirations about the world and, therefore, their actions were considered pre-political. Their culture was mainly oral because they were mostly illiterate (Hobsbawm, 1978, p. 12).

These people, who were neither born nor raised in a modern or capitalist world, were faced with the penetration of the relations of production and the logic of capitalism in their traditional world. The confrontation between these two realities produced conflicts, expressed in an archaic way and without political pretensions, in which kinship and other tribal ties had an important weight in the delimitation of the groups in conflict.

These societies, although pre-industrial, have long known the state, class distinctions and exploitation by landowners and traders; hence its protest is already a class protest. The fact that there are kinship ties and tribal solidarities is what fits them in primitive societies, but with class consciousness. And it was precisely the fact that they were class movements that interested the authors mentioned above.

For Thompson, the confrontation with a new capitalist practice changed the "moral economy" that governed traditional market practices in the 18th century, broke the paternalistic tradition and gave rise to social movements.

As in Europe, in Portugal there were several "primitive" social movements in the 1st half of the 19th century (Silva, 2007). Phenomena such as banditry or food riots took place during the period when the liberal and capitalist society was implanted. Banditry, not being a typical social movement, cannot fail to be considered a social phenomenon, because, although it was marginal, it was still important as a collective action of a group of individuals who defied the established order (Hobsbawm, 1978, p. 12) in an attempt to perpetuate the past, as their biggest problem was adapting to the new world they saw emerging. In the same way, the liberal state, by appointing people from outside the regions for administrative positions, created a certain distance between the local power and the populations, which facilitated the introduction of the laws of the capitalist market, without complacency by the traditional morality of the popular, generating food riots.

One of the arguments that is used to differentiate "archaic" and "modern" forms of protest is that the former do not undermine the foundations of the established social order and contribute to maintaining and reinforcing traditional and paternalistic ways of life, as Thompson says. In addition, they did not give rise to modern, organized and politicized social movements, which is why they fit in the classification of pre-politicians and reformists, and therefore are not revolutionaries (Hobsbawm, 1978, p. 15).

These forms of collective action, although they are usually labeled as "traditional", "primitive", or "pre-industrial", seeming even reminiscent of the past, show, however, in the first half of 
the 19th century, a clear role within the protest especially popular. At the same time, economic, political and social transformations brought new ideas and experiences that would deeply and permanently affect society, changing the character and forms of conflict. The progressive political reforms, the advance of capitalism and the modernization brought with industrialization, determined the gradual disappearance of the old forms of protest, because the persistence of the customs and rights of the past no longer made sense in a changing world. Local, spontaneous, sporadic and apolitical contests were replaced by "modern" protests, with national ideology and extension. The movements, according to Charles Tilly's terminology, go from "reactive" - because they have a limited "repertoire" of action, they include defensive practices in the face of external pressures (food riots, anti-fiscal protest, resistance to military service, hostility against machinery, land occupations, etc.) - for "proactive" actions, mainly from the middle of the 19th century, that is, more organized forms through an associative base: strikes, demonstrations, unions, giving rise to a new " repertoire "(Tilly, 1978, pp. 143155).

\section{Labor Movement}

In the 19 th century, industrialization has given rise to a new class, the working class. When it emerged, this group had no rights guaranteed by law, such as working hours, wages, or job security. They also had no right to demonstrate or strike, although these manifestations were happening throughout the 19 th and 20 th centuries.

The gap created between the capitalist bourgeois and the workers led to the class struggle and the organization of the workers through the workers' movement. The proletariat, over time, grew stronger and gained class consciousness, formed workers' associations and later unions, and with them the planned strikes emerged. The conflictual situation that was created in the industrial society between bosses and workers motivated by low wages, excessive working hours, poor working conditions, was expressed in the streets through demonstrations, marches, rallies or strikes (Silva, 2015). The strike was the extreme resource, because by breaking daily work relations it created a split, further evidencing class, economic and ideological conflicts. Even if the strike had its origins in economic divergence, it ended up joining strikers with militants from some party and became a means of political propaganda. However, the strike was and is the primary weapon of the collective action of unionism (Dias \& Fernandes, 2016, p. 41), in the sense of pressing for a beneficial solution for workers.

This associative movement strengthened the workers' organization, giving rise, in the second half of the 19th century, to a distinct, organized, politicized, unionized type of social movement that organized demonstrations and strikes at the national level, showing the conflictual situation existing between workers and capitalists. As in the rest of Europe, in Portugal, the conflict was motivated, essentially, by low wages, excessive working hours, poor working conditions. To demonstrate their dissatisfaction and demand better living conditions, the workers stopped working and protested, whether or not they were members of an association. In this country, the industrialization process was late and the workers were born with industry from the middle of the 19th century. This situation did not allow the formation of a class conscience among the workers, in the sense of the union of all factory workers, which is why it was only at the end of the 19th century that labor associations started to exist and only at the beginning of the 20th century (1910) the workers were entitled to strike. Here, similarly to what happened in the rest of Europe, the first workers' associations had a mutualistic character, with a cultural purpose and mutual support (Cabral, 1988, p. 19), as assistance in 
illness and death, memory of the old brotherhoods of crafts. This was the only chance of association, since the grouping by trades was prohibited in 1834 and was only authorized in 1891. Despite this prohibition, there were many strikes in the second half of the 19th century in the country. The right of association decreed in 1891 brought a certain union to the workers' movement, although the workers were not easily associated (Silva, 2015).

In Europe, the workers' movement was the expression of the conflict generated within industrial society, between capitalists and workers and is considered the first modern social movement.

Modern movements lose spontaneity, they are not movements that appear and disappear with the same speed as archaic ones, strikes can last for days, weeks or months, depending on the confrontation and the obtaining of complaints. They are organized movements that are based on the acquisition of better wage and work conditions, moving from economic and social demands to policies, especially after they are union organizations. The union gives legitimacy and legal framework to the strike, whether professional or general strikes. In the latter, the political character is well evident.

Both the primitive movements of the beginning of the 19th century and the strike movements of the second half of the century, although distinct, have a common element between them: the challenge to the world in which they lived. The former are forms of contestation due to the inadequacy of a liberal and capitalist world that disrespected the traditional way of life. The second is the reaction to the exploitation of a capitalism that only aimed at profit and that had at its base the bourgeois class that also dominated politics. The forms of protest used are completely different, the former are "reactive" and the latter "proactive", which changed the "repertoire" from the 18th to the 19th century. The consolidation of national states and the new industrial and urban society gave birth to a new form of politics and thus a new "repertoire", since it changes in accordance with the political and social structure (Tilly, 1995: 35). It was at the beginning of the 19th century that forms of organization were forged, such as parties, unions, strikes, rallies, demonstrations, considered socially legitimate to express demands (Tilly, 1995, p. 37).

\section{The New Social Movements}

From the sixties of the twentieth century, as society changed (Porta and Diani, 2006), new social phenomena were emerging. The social movements that emerged were derived from post-industrialization, no longer centered on labor movements and their struggle for economic and political transformation, nor framed by unionism, but were based on other value systems "structuring the consciences and identities of individuals and groups" (Teixeira, 1993, p. 811); conflicts became social and cultural. At the time of the first mobilizations, some theorists still thought that there was a return of the workers' movement, but it soon became apparent that they were not based on class but on other values such as civil rights or lifestyle. Authors like Touraine (1978) and Melucci (1996) understood social movements as a form of sustained collective action, from which actors who share identities or solidarities face dominant social structures or cultural practices. These authors considered the movements 
that emerged as New Social Movements (N.S.M), for having cultural motivations, being secondary to the search for advantages within the political system (Melucci, 1980, p. 220).

When they ceased to be movements of a class to be class movements, there was an atomization of the social movements themselves, hence the feminist movement, the ecological movement, the pacifist movement, emerged or intensified.

They are more segmented movements, driven by a new middle class (Habermas, 1986), which add members according to the ideologies of the groups, aim to affirm identities or improve the quality of life and which are inspired by non-materialistic values but universalist values, such as peace, the environment, autonomy and identity.

In the case of the feminist movement, it is the rights of women: legal and citizenship, which lead to collective action for them to be recognized contractual, property and voting rights.

The ecological movement fights for a new form of rational and sustainable development, changing forms of production, exploiting resources with environmental counterparts, irrational and inconsequential consumerism.

Pacifist movements fight for ideals of peace, in a non-violent way through resistance, boycotts, diplomacy.

In Portugal, as a result of the dictatorship that the country lived in the sixties (1933-1974), known as Estado Novo and led by António de Oliveira Salazar, the cultural movement that most asserted itself was the student one, although there was also some female contestation and worker. Even under dictatorship, students had contact with what was happening in the world, namely the "May of 68", which gave strength to the movement of students to unite and fight for freedom of association, the end of the colonial war and the opening from civil society to student academies. These students demonstrated in favor of new values, like many young people around the world, hence they were against war as a principle, and not just the war of the Portuguese colonies (Silva, 2014). In 1968, they met in front of the United States Embassy against the war in Vietnam. These protests were violently suppressed, but they strengthened the student movement (Cerezales, 2011).

The New Social Movements have in common the fact that they are politicized forms of contestation, although they did not aim for a political revolution, hence the non-integration in parties or unions and the demonstration in the public sphere, through rallies or parades, noninstitutional processes of action, recruiting its actors in different social media. The aim was to make themselves visible to bring public opinion to their cause and have political effects. As Claus Offe says to be able to emancipate from the State, political rights must be acquired (1992, p. 166). These are movements that aim to acquire democratic privileges. These new protagonists, young people, students, women, professionals, focus their struggle no longer on living conditions or redistribution of resources but on the quality of life and the diversity of styles of living it.

Throughout the 20th century, the nature of capitalism changed, but not the political-economicsocial structure. The center ceased to be industrial production and workers, thus giving way to new themes and agents for collective mobilizations, although coexisting with previous ones. Therefore, the "repertoire" remains, but with "a variable set of performances" (Tilly, 2005, p. 
216). Taking into account the culture, identity and political conditioning of a given society, actors improvise in social interactions (Tilly, 2008).

\section{Inorganic movements}

The social movements witnessed in the 21st century, call into question the way democracy itself is being exercised in the current era, given that the "main objective of democracy must be to allow individuals, groups and collectivities to become free subjects, producers of its history, capable of bringing together in its action the universalism of reason and the particularities of personal and collective identity "(Touraine, 1995, p. 263).

It is not a challenge to have more rights but to exercise those that exist, full citizenship, which offers the freedom to express opinion and the privilege of participating in the political, economic, social, educational area. There are several types of movements of this kind in the European space: "Geração à Rasca”, "Que a Lixe a Troika”, "Occupy”, "Indignados”.

In these movements, individuals, as citizens, intervened in the public sphere and spoke about issues that related to them, such as the crisis, unemployment, exploitation, as people belonging to a collective. They were manifestations of displeasure from civil society in relation to real life situations that they considered unworthy for citizens and that they should express for living in democracy and for being an active part of that democracy. According to the demonstrators, citizenship should not be exhausted in the electoral act.

The mobilization was identical in all. The challenge was launched on social media, and thousands of Europeans took to the streets to protest the precariousness of work, the austerity measures imposed by governments, the reduction of taxes, the lack of dignity in which citizens lived as a result of decisions policies.

Through social networks, camps, street protests, they expressed the feeling of different quarters of society in relation to the crisis, to governments, to the political class, making it clear that they could not always be the same to charge and the same to continue to pay.

These movements claimed to be non-partisan, without affiliation to parties and unions, secular, peaceful and without formal organization. Despite this, they suffered some repression due to the fear of contagion that caused elites, resulting in some police clashes. Their lack of insertion in any organized structure was also a target of fear because they were movements that channeled various social groups that no longer believed in political parties, regardless of which political family they were in, nor in unions to represent them. These "brand new" movements are not very heterogeneous, with little negotiable objectives and maintain an ambiguous relationship with political power (Cabo, 2008: 51). They believed that change was taking place in new ways, without leadership or bureaucratic organizations but resorting to solidarity.

The social movements of the 21st century present a different configuration from the so-called N.S.M, in the form of organization, dimension, disclosure, national and international media impact. It is through social networks that they organize and manage to mobilize thousands of people in several cities in the same country or even from different countries. They reach a dimension that goes beyond regional and national scales and become planetary movements, in search of new forms of democracy (Farro, 2004). Communication technologies, especially social networks, have incorporated new forms of activism, netativism (Di Felice, 2012), which escapes the institutional powers, as they emerge from diverse social, political and cultural 
configurations (Babo \& Silva, 2019), introducing changes in the form of social action. However, the mobilizations from the internet, although inserting new performances of action, do not break with traditional forms, as seen by the need for co-presence in a physical space, the symbolism of the action (historical places, posters ...), the street emotion through speeches and music. At the same time, the use of the internet endows these collective actions of visibility and speed by the instantaneous nature that mobile devices allow, shorten distances and empower citizens. They are mobilizations that start from social networks, thus facilitating collective action in urban spaces, innovating in the "repertoire" but not changing it. As Tilly advocates, "repertoire" involves "shared understandings, memories and agreements" (Tilly, 1995, p. 30), just as it happened in these movements. The mobilization in a network implied novelty in the existing forms of action or "repertoire", but without entirely breaking with the old ways (Tilly, 1995, p.27-28). These protests, being structurally situated, remove the historical and cultural void that led to a great singularity or to a change of "repertoire", which can be framed in cycles of protests, albeit with modular innovation (Tarrow, 1998).

\section{Conclusion}

Collective action, as the European and American paradigms emphasized, was motivated by several factors, from the acquisition of rights to their maintenance. In these last protests, citizens contest for a new world. Therefore, today, the movements are more complex, as Melucci says "many of the contemporary conflicts are the expression of excluded social categories that want to be socially represented" (Melucci, 1996, p. 104-105), and mean that there are more and more "actors in conflict".

In this century, Social Movements have become the catalysts for social conflict, due to their "institutionalization" as a necessary social actor for the improvement of democracy. Thus, in the crossing of the nineties and the beginning of the 21st century, social movements acquired a key role as a political actor in a democratic State, due to the importance recognized as a legitimate bearer and dynamic representative of demands from different sectors of civil society (Machado, 2007).

As long as the liberal political-economic-social model is in place, it is difficult for the forms of action to change completely, with new "repertoires" appearing. In the current manifestations in Europe there is a flexible "repertoire", in which there is continuity and improvisation (Tilly, 2008 , pp. 13, 14) in the forms of claim, since the forms of action are based on "social relations, meanings and actions mixed in known and recurring patterns "(Tilly, 1995: 30). However, today we live in a technological society, in a network (Castells, 1999) which, according to thinkers like Di felice, is giving rise to new "communicative forms of living" that alter our habitation condition, our relationship with the environment, with the territory, building a "post-urban" society (2009). According to Di Felice, the paradigms of modernity are no longer adequate to understand our days. In this sense, it is possible that a new "repertoire" of collective action is being forged, but until now social movements are not a totally new phenomenon and still require historical understanding.

\section{References}

[1] Babo, I.\& Silva, C.T. (2019).Redes sociais e mobilizações públicas. O movimento de 15 de Setembro. In Luciana Pavowski Franco Silvestre (Org.) Ciências Sociais Aplicadas: 
entendendo as necessidades da sociedade, v 2., (pp.151-165).

[2] Cabo, A. I. (2008). Os Novos Movimentos Sociais e os Media. Lisboa: Livros Horizonte.

[3] Cabral, M. (1988). Portugal na alvorada do século XX. Lisboa: Presença.

[4] Castells, M. (1999). A Era da Informação: Economia, Sociedade e Cultura - A Sociedade em Rede. São Paulo: Paz e Terra.

[5] Cerezales, D. P (2011). Portugal à Corunhada. Protesto popular e ordem pública nos séculos XIX e XX. Lisboa: Tinta da China.

[6] Cohen, J. L. (1985). Strategy or identity: new theoretical paradigms and contemporary social movements. Social Research, 52 (4), pp. 663-716.

[7] Della Porta, D. \& Diani, M. (1999). Social Movements. An Introduction.Oxford: Blackwell Publishers.

[8] Di Felice, M. (2009). Paisagens Pós-Urbanas. 0 fim da experiência urbana e as formas comunicativas do habitar. S.Paulo: Annablume.

[9] Di Felice, M. (2012). Netativismo: novos aspectos da opinião pública em contextos digitais. P. Alegre,v.19, n.1, pp.27-45.

[10] Diani, M. (1992). The concept of social movement. The Sociological Review, 40 (1), 125.

[11] Farro, A. (2004). Actors, conflits and globalization movement. Current Sociology. Vol.52. Londres: Sage.

[12] Fernandes, A. T. (1993). Conflitualidade e Movimentos Sociais. Análise Social, vol.XVIII (123-124), pp.787-828.

[13] Gohn, M. G. (1997). Teoria dos Movimentos Sociais: paradigmas clássicos e contemporâneos. São Paulo: Loyola.

[14] Habermas, J. (1986 [1981]). The Theory of Communicative Action. The Critique of Functionalist Reason, vol. 2, Cambridge: Polity Press.

[15] Hobsbawm, E. (1978). Rebeldes Primitivos. 2a ed. Rio de Janeiro: Zahar Editores, 1978.

[16] Jasper, J. (2012). De la estructura a la acción? La teoría de los movimientos sociales después de los grandes paradigmas. Sociológica, 27, pp. 7-48.

[17] Machado, J. A. (2007). Ativismo em rede e conexões identitárias: novas perspetivas para os movimentos sociais. Sociologias, nํ18, Julho-Dezembro. Porto Alegre.

[18] McAdam, D., Tarrow, S., Tilly, C. (2001). Dynamics of contention. Cambridge: Cambridge University Press.

[19] McAdam, D. (1996). Conceptual origins, current problems, future directions, em Doug McAdam, John D. McCarthy e Mayer N. Zald (orgs.),Comparative Perspectives on Social Movements. Political Opportunities, Mobilizing Structures, and Cultural Framings. Cambridge: Cambridge Universty Press, pp. 22-40.

[20] Melucci, A. (1980). The new movements: a theoretical approach. Social Science 
Information, 19, 2, pp.199-226.

[21] Melucci, A. (1996). Challenging codes - collective action in the information age. Cambridge: University Press of Cambridge.

[22] Offe, C. (1992). Partidos políticos e nuevos movimientos sociales. Madrid: Editorial Sistema.

[23] Silva, C. T. (2007).Movimentos sociais no Douro no período de implantação do liberalismo (1834-1855).Porto: Gehvid.

[24] Silva, C.T (2014). Social Movements in Contemporary Portugal. European Journal of Social Sciences Education and Research (EJSER). Vol.1, no․ August 2014. Rottenburg: European Center for Science Education and Research, pp.36-43.

[25] Silva, C.T (2015). Worker's protests in Northern Portugal in the transition from the monarchy to the I Republic. Mediterranean Journal of Social Sciences (Scopus index MJSS). Vol.6, nํ⒉, S5, April 2015. Rome: Mediterranean Center of Social and Educational Research, pp.115-119.

[26] Tarrow, S. (1998). Power in Movement. Social Movements and Contentious Politics. Cambridge, Cambridge University Press.

[27] Thompson, E. (1979). La Economia «Moral» de la multitud en la Inglaterra del siglo XVIII.Tradición, Revuelta y Consciencia de Clase. Barcelona: Crítica.

[28] Tilly, C. (1978). From Mobilization to Revolution. New York: Random House.

[29] Tilly, C. (1981). As sociology meets history. New York: Academic Press.

[30] Tilly, C. (1995). Contentious repertoires in Great Britain, 1758-1834. In M.Traugott, (Org.),Repertoires and cycles of collective action(pp. 15-42). Durham, NC: Duke University Press.

[31] Tilly, C. (2005). identities, boundaries \& socialities. London: Paradigm Publishers.

[32] Tilly, C. (2008). Contentious Performances. Cambridge: Cambridge University Press.

[33] Tilly, C. \& Tarrow, S. (2006). Contentious Politics. Londres: Paradigm Publishers.

[34] Touraine, A. (1978). La Voix et le Regard. Sociologie des Mouvements Sociaux, Paris,Editions du Seuil.

[35] Touraine, A. (1995). La producción de la sociedad. Mexico: Ilsunam.

[36] Touraine, A. (1996). O Retorno do Actor, Lisboa, Instituto Piaget.

[37] Touraine, A. (1998). Pourrons-Nous Vivre Ensemble?, Paris, Editions Fayard 